\title{
Small Size Protected Areas - Development Potentials of Slovenia
}

\author{
Irena Mrak
}

\begin{abstract}
A well preserved natural environment, a high level of biodiversity and a unique mosaic landscape structure in Slovenia has led to a relatively high percentage of protected areas, areas of Natura 2000, as well as ecologically important areas. Protected areas are mainly recognized as development restriction and rarely as development opportunity, although they are more a coincidental result of past spatial planning and nature preservation. The paper presents two smaller study areas - a natural monument and a landscape park. The two cases show the present activation of natural values and the rate of inclusion of protected area potential into endogen regional development. The sustainable regional development with activation of various protected area's potentials is still at the beginning and will only be developing through the efficient management system as well as with encouragement of social capital and human resources development.
\end{abstract}

Keywords: sustainable development, protected areas, Dovžan Gorge Natural Monument, Landscape Park Lahinja, Slovenia.

\section{Mala zaštićena područja - razvojni potencijali Slovenije}

Dobro očuvana prirodna sredina, visoki stupanj bioraznolikosti i jedinstvena mozaička struktura krajolika Slovenije doveli su do relativno visokog udjela zaštićenih područja, područja Natura 2000, kao i ekološki značajnih područja. Zaštićena područja se uglavnom smatraju kočnicom, rijetko kao prilika za razvoj, što najviše proizlazi iz rezultata prostornog planiranja i zaštite prirode u prošlosti. Članak predstavlja dva manja područja istraživanja - spomenik prirode i park prirode. Ta dva primjera pokazuju sadašnju valorizaciju prirodnih vrijednosti i stupanj uključivanja potencijala zaštićenog područja u regionalni razvoj. Održivi regionalni razvoj uz aktivaciju različitih potencijala zaštićenog područja još uvijek je na početku, a razvijat će se samo uz efikasan sustav upravljanja s poticanjem društvenog kapitala i razvoja ljudskih resursa.

Ključne riječi: održivi razvoj, zaštićena područja prirode, Dovžanov kanjon, park prirode Lahinja, Slovenija 


\section{INTRODUCTION}

Slovenia is one of the geographically most diverse countries in Europe. The landscape variegation is shown in five major landscape units: Alpine, Subalpine, Subpanonian, Karst-dinaric and Submediteranean. Each unit has a very high level of biodiversity, numerous nature values, a high percentage of ecologically important areas, a high percentage of protected areas and also a high percentage of "Natura 2000".

Until recently Slovenia has protected $11 \%$ of the state territory and until May 2004 it defined areas of Natura 2000 (over 36\%); beside that, the forested areas cover over $60 \%$ and rural areas by some typologies encounter as much as $90 \%$ of rural landscape with $60 \%$ of total population.

Slovenia was able to preserve the unique settled rural areas (altogether approx. 6000 settlements) although from a demographic perspective, nearly half of the settlements (approx. 3000) face with population decline; almost 700 settlements are endangered by very fast depopulation tendencies (Kladnik, Ravbar, 2003).

It is the high landscape variegation and biodiversity that present the unique, and not yet well-activated, development opportunity of Slovenia. The basic goals of the Development Strategy of Slovenia (2005) are:

- Overall intergenerational and sustainable development of Slovenia.

- Overall improvement of the quality of living.

- To overcome the average stage of EU economic development and to rise the employment rate.

- To be a practitioner of "development good practice" at the international level.

The Development Strategy of Slovenia also requires the integral sustainable development of protected areas that would, with their natural properties, become recognized as a quality of wider European importance. That would be a Slovenian specialty as well as a strategic development advantage.

\section{HISTORY OF NATURE PROTECTION IN SLOVENIA}

The exceptional natural values of Slovenia led to relatively early start of nature protection. Until 1918 nature protection in the area of Slovenia was limited to rare individuals, tourism and hunter clubs to take care of special natural values, building visitor trails enabling, the first tourism development and also protecting nature. The count Auersperg was one of the first to emphasize the importance of natural values in Slovenia. In 1888 count Auersperg decided to exclude 305 hectares of natural forest from the economic use in the region of Kočevje in order to protect it for future generations. The first initiative for the special law on nature protection was given by dr. L. Dimitz, the forest expert, in 1909. 
In 1920 the Nature Protection Section of the Museological Society of Ljubljana addressed a memorandum to the regional government for the:

- Establishment of alpine, mountain and marsh protected areas.

- A law banning the destruction of rare, typical and scientifically important animals and plants.

- The survey and protection of underground caves with interesting flora and fauna.

- Encourage the wider public interest for nature protection in general.

This memorandum was the basis for the "Ordinance on rare and typical scientifically important animals and plants, and cave protection in Slovenia".

Seismologist Albin Belar gave the first initiative for the establishment of a national park in 1908. He suggested the protection of the Valley of Triglav lakes in the Julian Alps but due to World War I all the protective actions were stopped. In 1924 the state forest management excluded 1600 ha of the area around Triglav Mountain and proclaimed it as "Alpine Protection Park" for the period of 20 years. From the legislative point of view nature protection was a part of forestry law from 1929 and the construction law from 1931. In 1938 the Ordinance on National Parks enabled the protection of special nature

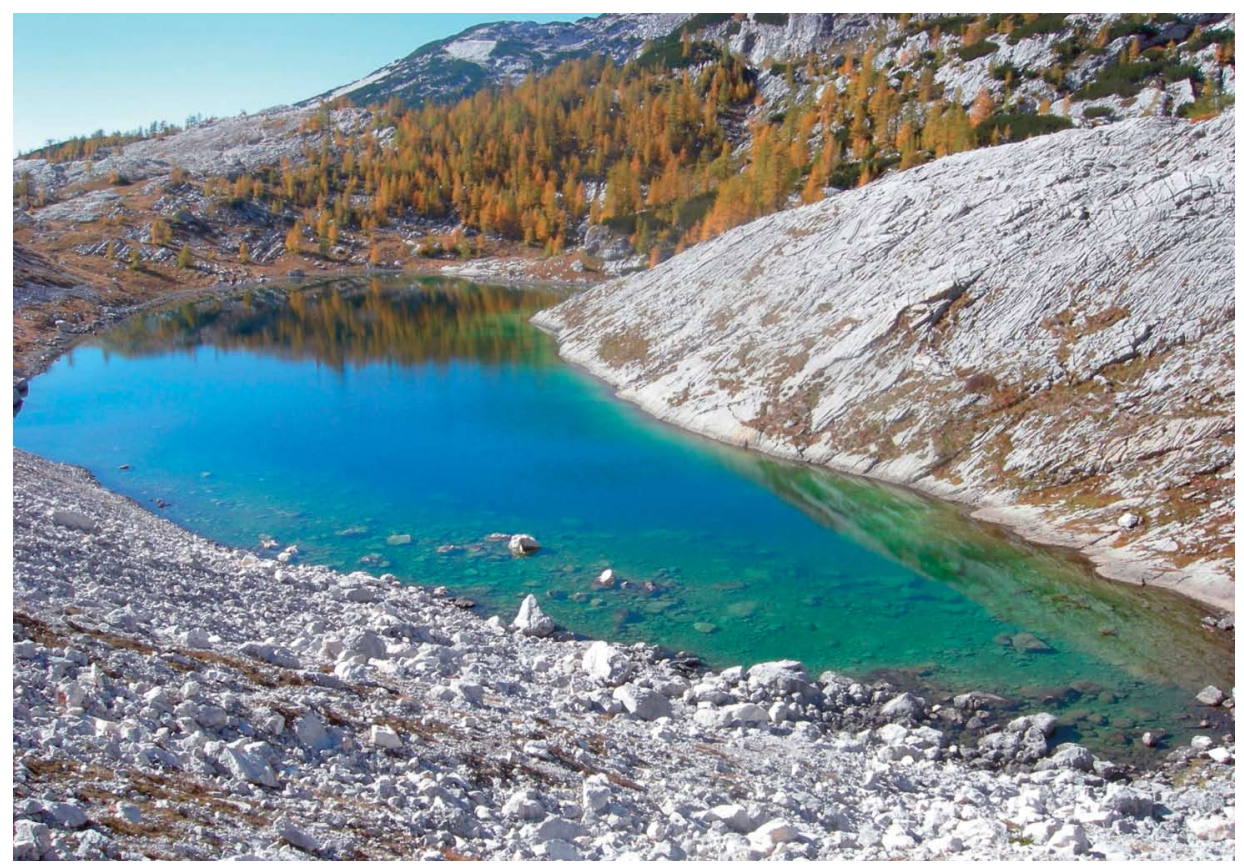

Fig. 1 Valley of Triglav lakes in Julian Alps is in the core area of Triglav National Park

Sl. 1. Dolina Triglavskih jezera u Julijskim Alpama u središnjem dijelu Nacionalnog parka Triglav

Photo: I. Mrak 
values of scientific and historical importance and/or those that were important for tourism development as well as for nature enjoyment and/or were physically and psychologically important for citizens (Piskernik, 1964).

After World War II the new protected areas were proclaimed and in 1944 the contract of the "Alpine Protection Park" expired. It was only in 1961 that the decree on the new national park was accepted. The Valley of Triglav lakes was proclaimed as a Triglav National Park. The protected area encountered 2000 ha. In 1981, 20 years after the proclamation, the protected area was enlarged and the special law on Triglav National Park recently covers 83807 ha (Šolar, 2001). Simultaneously to Triglav National Park other

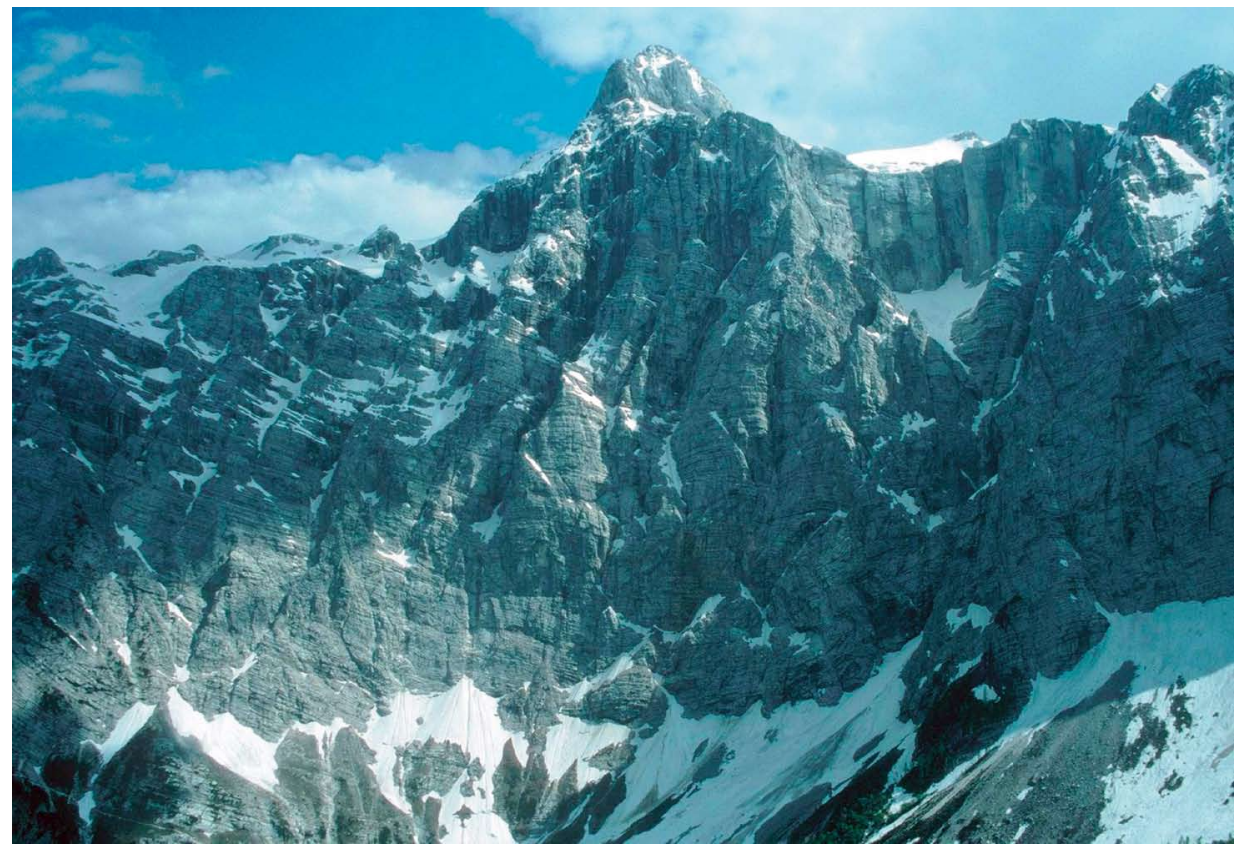

Fig. 2 North face of Triglav

Sl. 2. Sjeverni dio Triglava

Photo: I. Mrak

protected areas were proclaimed; proposed mainly by the regional Nature Protection and Cultural Heritage Preservation Agency. The two case study areas were protected in 1988 by municipality decrees.

\section{THE RECENT SITUATION OF PROTECTED AREAS IN SLOVENIA}

According to the law on nature protection, the wider protected areas (national park, regional parks and landscape parks) recently cover approximately $1900 \mathrm{~km}^{2}$ or around $9 \%$ of Slovenia. Together with nature reserves and natural monuments, protected areas cover 


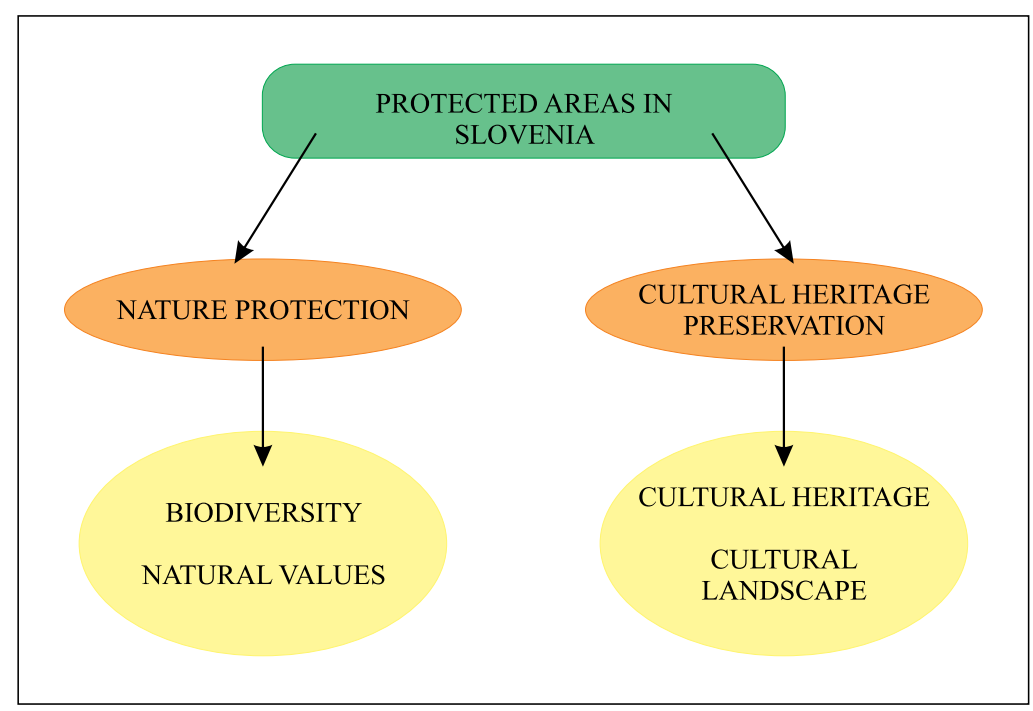

Fig. 3 Protected areas in Slovenia are the result of historical nature protection development as well as the culture heritage preservation.

Sl. 3. Zaštićena područja u Sloveniji su razultat povijesnog razvoja zaštite prirode kao i očuvanja kulturnog nasljeđa

almost $11 \%$ of the territory of Slovenia. The percentage of protected areas in comparison to other European countries ranks Slovenia in the bottom part of the international scale (Berginc, 2006).

Nature protection is defined through the Law on Nature Protection from 1999 (Zakon o ohranjanju narave, Ur.l. R.S., 56/99) and protection of cultural heritage through the Law on Cultural Heritage Protection from 1999 (Zakon o varstvu kulturne dediščine, Ur.l. R.S., 7/99). Triglav National Park has its own law, whereas other wider protected areas, such as landscape parks, regional parks, natural monuments and natural reserves, have their own special decrees.

Tab. 1 Types, numbers and size of protected areas in Slovenia according to the IUCN categories.

Tab. 1. Tipovi, brojevi i veličina zaštićenih područja u Sloveniji prema IUCN kategorijama

\begin{tabular}{|c|c|c|c|c|c|}
\hline Wider protected areas & No. & Size & $\begin{array}{c}\text { \% of state } \\
\text { territory }\end{array}$ & $\begin{array}{c}\text { Smaller protected } \\
\text { areas }\end{array}$ & No. \\
\hline National park & $\mathbf{1}$ & $838 \mathrm{~km}^{2}$ & $4.1 \%$ & $\begin{array}{c}\text { Strict Nature Reserve/ } \\
\text { Wilderness Area }\end{array}$ & - \\
\hline Regional park & $\mathbf{3}$ & $418 \mathrm{~km}^{2}$ & $2.1 \%$ & Nature reserve & $\mathbf{5 2}$ \\
\hline Landscape park & $\mathbf{4 2}$ & $646 \mathrm{~km}^{2}$ & $3.2 \%$ & Natural monument & $\mathbf{1 2 1 7}$ \\
\hline
\end{tabular}




\begin{tabular}{|c|c|}
\hline Category & Description \\
\hline National Park & $\begin{array}{l}\text { National Park includes wider areas with numerous nature values as } \\
\text { well as a high level of biodiversity. In the majority national parks, } \\
\text { nature is pristine and the ecosystems and natural processes are } \\
\text { preserved. In the minority part of national parks human activities can } \\
\text { be observed but need to be in harmony with the natural environment. }\end{array}$ \\
\hline Regional Park & $\begin{array}{c}\text { Regional Park includes a wider area of typical regional ecosystems and } \\
\text { landscape with areas of pristine nature and preserved natural values } \\
\text { that are also in harmony with human activities in the area. }\end{array}$ \\
\hline Landscape Park & $\begin{array}{c}\text { Landscape Park is the area that reflects a long and qualitative harmony } \\
\text { of human activities and nature. These areas have high ecological, } \\
\text { biodiversity and landscape values. }\end{array}$ \\
\hline Strict Nature Reserve & $\begin{array}{l}\text { Strict Nature Reserve is an area of preserved habitats of endangered, } \\
\text { rare and typical species; or an area important to preserve the } \\
\text { biodiversity where there natural processes are in continuation with } \\
\text { complete human absence. }\end{array}$ \\
\hline Nature Reserve & $\begin{array}{c}\text { Nature Reserve is an area of preserved habitats of endangered, rare } \\
\text { and typical species; or an area important to preserve the biodiversity } \\
\text { where there natural processes are balanced with the human activities in } \\
\text { natural environment. }\end{array}$ \\
\hline Natural Monument & $\begin{array}{l}\text { Natural Monument is an area of one or more nature values that } \\
\text { have special form, appearance, quantity and position; or are the rare } \\
\text { example of a nature value. }\end{array}$ \\
\hline
\end{tabular}

Source: Ministry of Environment and Spatial Planning, 2006.

At present, there are still 2 landscape parks and 7 regional parks yet to be proclaimed. In the National Program of Environmental Protection 2006 - 2012 (UL 2/2006), the enlargement of protected areas to $15 \%$ to 2008 and to $20 \%$ to 2014 is expected.

Due to EU requirements, Slovenia introduced Natura 2000 as a mechanism for the Council Directive 92/43/EEC on conservation of natural habitats and of wild fauna and flora and of the Council Directive 79/409/EEC on the conservation of wild birds. The average percentage of Natura 2000 in EU countries is $15 \%$ whereas in Slovenia it is much higher - over $36 \%$. The percentage is the consequence of the relatively preserved natural environment in the country.

According to SPA (Special Protected Areas - ecologically important areas which are at the EU level deemed important in order to preserve bird species as well as other vegetation and animal species, their habitats and habitat types), Slovenia protected 26 areas or $22.8 \%$ of territory and according to SCI (Sites of Community Interest), 260 areas are protected, covering $31.5 \%$ of Slovenia. $9 \%$ of Natura 2000 is the area above $900 \mathrm{~m}$ above sea level and $70 \%$ of the total, represents forests (Ministry of Environment and Spatial Planning, 2006). 


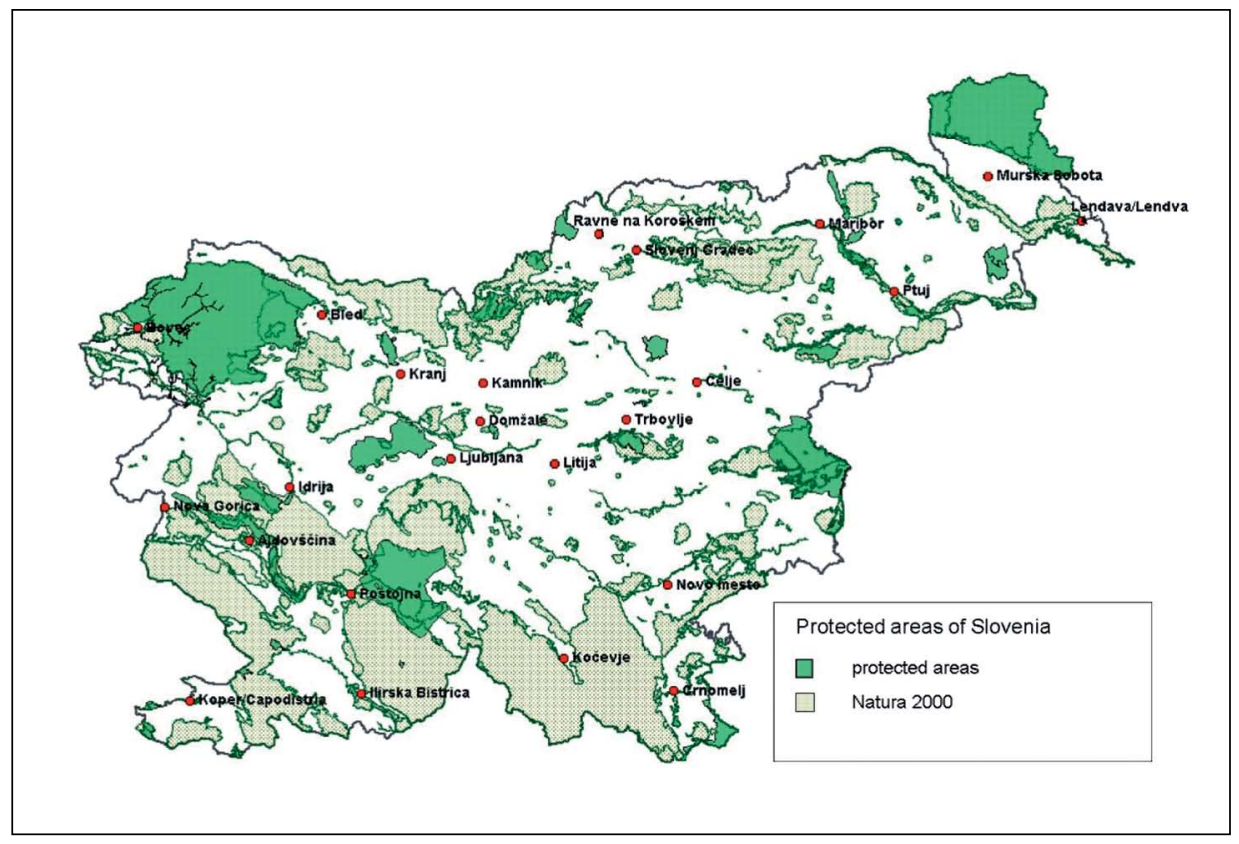

Fig. 4 Map of protected areas and the areas of Natura 2000 in Slovenia.

Sl. 4. Karta zaštićenih područja i područja Natura 2000 u Sloveniji

Source: Ministry of Environment and Spatial Planning, 2006.

Izvor: Ministarstvo okoliša i prostornog planiranja, 2006

The Environmental Agency of Slovenia, the Sector for Nature Conservation is in charge of biodiversity conservation, and of the conservation of nature values on the basis of European and Slovene legislation as well as international conventions. Their role is to follow the legislation, to define the protected areas, to survey them and to stimulate the development activities. On the other hand, the majority of protected areas are being proclaimed as "local" importance and therefore they are the concern of local communities - mainly municipalities; where budget for protected areas is limited and the protected areas among the local population are understood as development restriction. Local population often feel disturbed by the protection regimes and due to the lack of knowledge on nature protection they are against the proclamation of new protected areas (Mrak, Potočnik Slavič, 2004).

The sustainable development of protected areas and areas designated Natura 2000, is an important part of regional development in Slovenia, that tends to have a balanced economic, environmental, social, cultural as well as spatial development of all regions. Since protected areas are present throughout Slovenia they therefore present a development potential that is waiting for it's opportunity; especially in tourism, eco farming and education. The activities that are and will be emerging in such areas will require also innovative management as a crucial part of endogen regional development. 


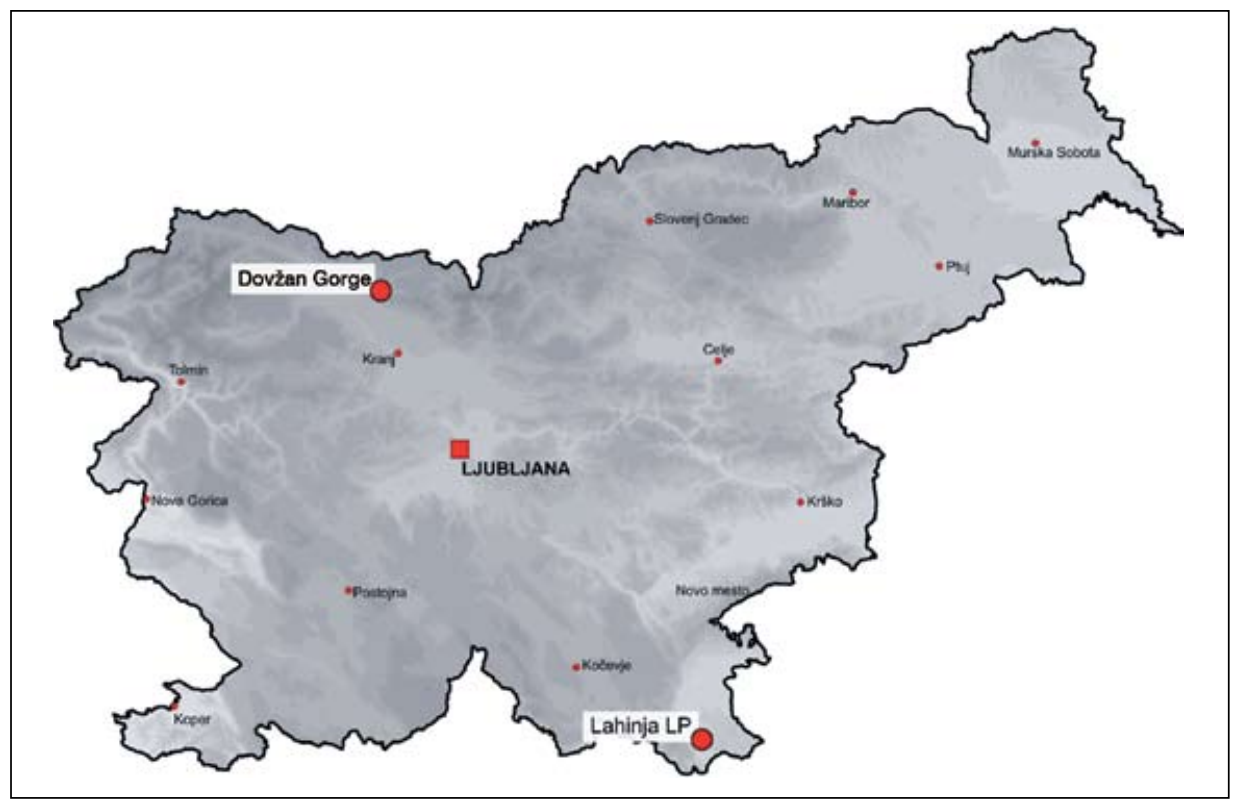

Fig. 5 Case study area location.

Sl. 5. Lokacija područja istraživanja

\section{THE RESEARCH "Living in a protected area in Slovenia"}

From 2003 on, the research "Living in a protected area in Slovenia", is run by the Department of Geography (Faculty of Arts), University of Ljubljana. The research looked at protected areas in different protection categories in different regions of Slovenia.

For the research local population was interviewed using the so called »snow ball« technique. The interviewees were inhabitants of the protected area but they were randomly chosen. The first part of the questionnaire was dedicated to the personal attitude towards the protected area where they lived. In the second part we were asking the interviewees to point out positive and negative effects of the protected area they lived in and in the final part the interviewees were asked to estimate the role of local decision makers and the state in protected area development as well as their own future role in protected area development.

The two case studies presented in this paper: Dovžan Gorge Natural Monument situated in Karavanke mountains, near the border of Austria, and Lahinja Landscape Park located in the south-eastern part of Slovenia at the border of Croatia.

\section{CASE STUDY I: DOVŽAN GORGE NATURAL MONUMENT}

Dovžan Gorge was protected as a natural monument in 1988 by Tržič Municipality regulation. This 180 hectares section of land for unique by its geologic, geomorphologic and biologic characteristics, and has been researched by scientists for more than a century. 


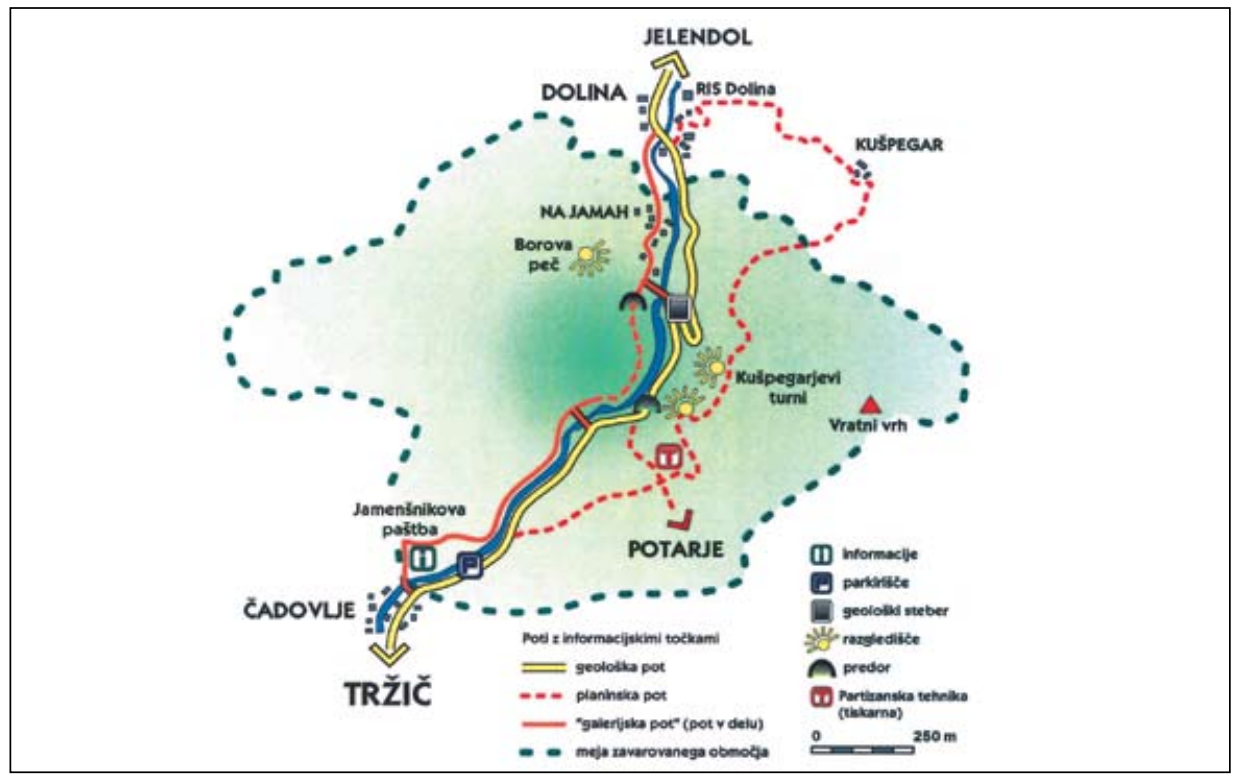

Fig. 6 Sketch of the protected area. The inner 80 hectares are protected more severely than the outer 100 hectares of the area, where some economic activities are still allowed.

Sl. 6. Skica zaštićenog područja. Unutarnjih 80 ha područja je strože zaštićeno nego vanjskih 100 ha, gdje su još uvijek dozvoljene neke gospodarske djelatnosti.

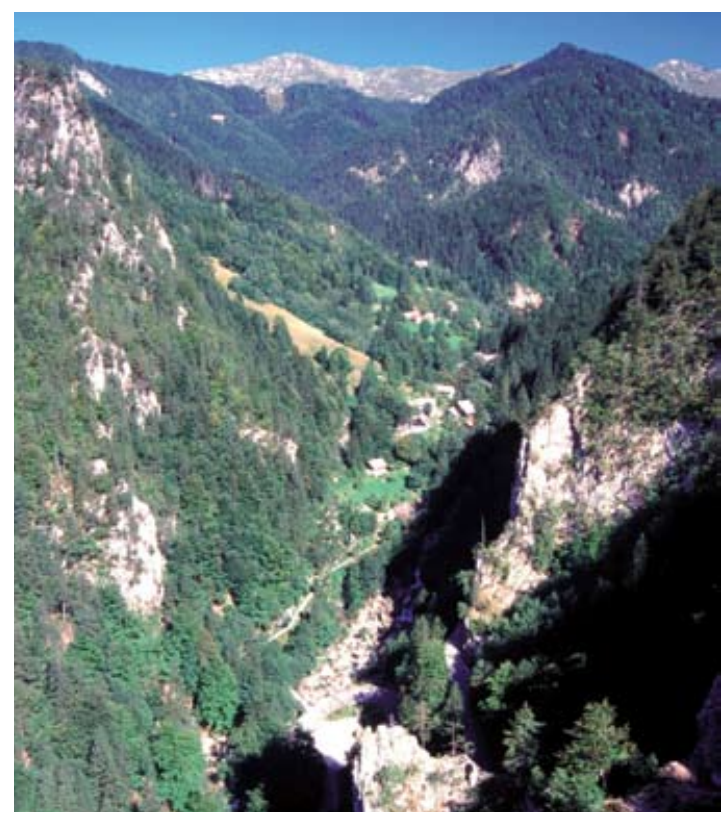

Fig. 7 The core area of the protected area. Viewing north.

Sl. 7. Središnji dio zaštićenog područja. Pogled prema sjeveru.

Photo: I. Mrak 
In 1994 the area management plan was made precisely to indicate the future development of tourist trails, their development and accompaniying infrastructure. The local population was also involved while writing the plan.

From 1994 to 1999 the development activities were financed by state and municipal budgets. In the years 1997, 1998, and 1999 funds were also obtained from the European Union programs (PHARE CBC Project Fund). The funds allowed the establishment of tourist trails, their equipment with information plates and the renovation of the previous village primary school in the settlement of Dolina into the visitor center. The work to reconstruct the local water pipeline also started.

The marketing of the area slowly started through guided tours with specially trained local tourist guides. The marketing target groups were and still are mostly pupils from primary and secondary schools and students from various parts of Slovenia. Individual visitors rarely hire a local guide and usually just use the trail infrastructure and promotional materials.

The income from guided tours is partially used for tourist infrastructure maintenance. The funds generated, however, are not sufficient so a part of the municipal budget is still dedicated to the area of natural monument.

The regional office for nature conservation in the nearby regional center Kranj takes a survey of the activities in the area. In accordance with the state law on nature conservation the Dovžan gorge natural monument is protected as a "natural monument of state importance".

After 19 years of protection the Dovžan Gorge Natural Monument is still not managed and organized sufficiently. The unique natural and cultural heritage of the area is partially

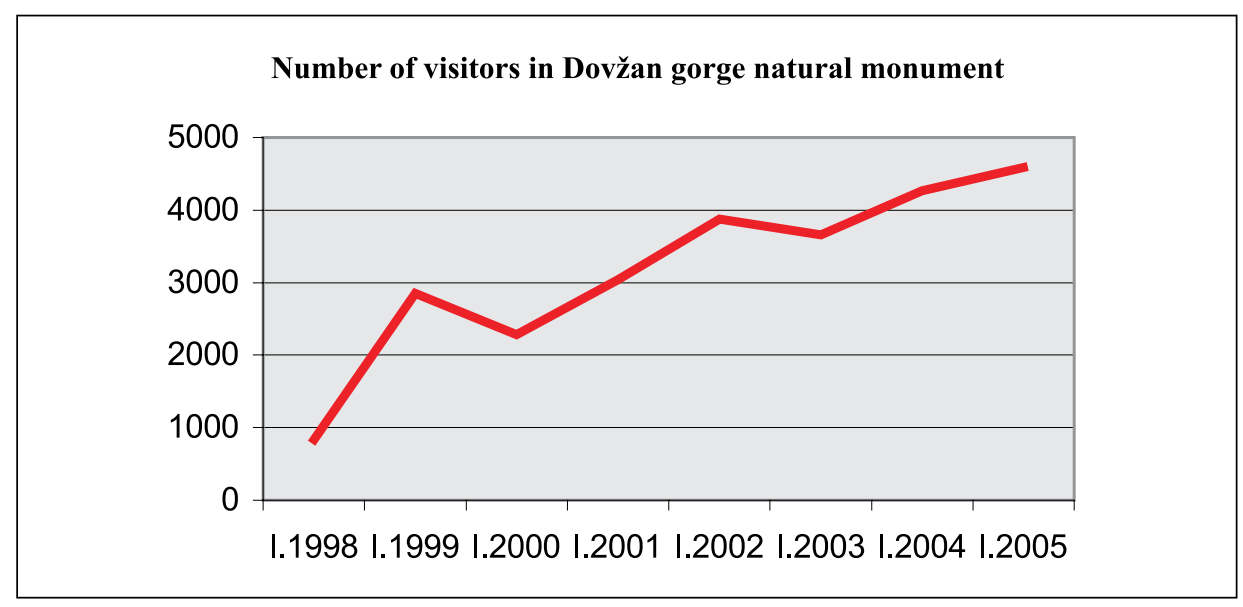

Fig. 8 Number of visitors in Dovžan gorge from 1998 - 2005 (guided groups only).

Sl. 8. Broj posjetitelja u Dovžanovom kanjonu 1998.-2005. (samo organizirane grupe).

Source: Municipality of Tržič, 2006.

Izvor: Općina Tržić, 2006. 
presented through some promotional materials, the area has guided tours but the income generated is insufficient to cover the costs of basic tourist infrastructure maintenance; as well as the funds needed for future service development.

The interviews were carried out in June 2003, respecting the representative sample (33 locals; $10 \%$ of local population). The sample considered present age structure categories, gender and social structure. We researched the most important problems of the local population in connection to the protected area. We also asked about their future development vision of the Dovžan Gorge and their (potential) personal role in the protected area.

The questionnaire included the working age, youngsters (supported population) and retired population. The results showed a relatively unfavorable educational structure. The majority of the interviewees do not own land in the protected area. Approx. 2/3 of the interviewees were »natives «, living in the area all their lives. $2 / 3$ of the interviewees support the idea of protected areas; the idea of protected area enlargement was supported by a half of those interviewed. These results directly "clash" with the present protected area situation (lack of road structure maintenance, insufficient supply services, etc.) showing a certain stage of discrepancy. The majority of the local population find the existing protection system of the central area "too rigorous", whereas, concerning the outer area protection system the population is conflicted.

Three quarters of those interviewed consider the present milieu offers them "a high quality of life". The local population miss the road (its suitable renovation), an inn, more TV channels (only two at present), a shop and church; young people miss entertainment and playgrounds; the lack of interest for tourism development is evident. The main positive outcome of the protected area (following the questionnaire results) is the area's recognizability. They consider the protection of natural and cultural heritage as important. Some of them believe that a protected area is a development challenge. Only a few see the benefits of tourist visits and tourist outcomes. On one hand - they would like to gain the visitors, on the other hand - they are not able to offer a suitable tourist infrastructure.

The interviewees considered garbage (left by the visitors) and bad road infrastructure as the major deficiencies of the present protected area. The owners of arable land consider the existing restrictions for agriculture as negative for agricultural development. 2/3 criticize the attitude of the Municipality of Tržič towards the protected area: usually exposes inconsistency, work unfinished, and not kept promises. In spite of all mentioned deficiencies and problems, 2/3 of interviewees intend to stay in the area (they already own property, are older, or they like the area - »it is quiet, green and beautiful «). In the case of possible protected area enlargement they do not intend to be involved actively $(2 / 3$ of interviewed), exceptionally they find this as a development opportunity (for a new shop or inn opening, for a job as protected area manager).

The interview showed the local population's positive opinion about the protection of the area as well as to possible future enlargement to the regional park Karavanke in Kamniško-Savinjske Alps. Still unclear is the present and future involvement of the local population in the protected area. The potential active involvement could not be sensed but that could also be the consequence of past and present municipal policy in the area as well as of the activities of the regional professional structures. 
On the basis of the thorough research of the area two development scenarios have been created. The first scenario is based on the maintenance of the present conditions and the second proposes thorough changes in the natural monument's future development.

\begin{tabular}{|c|c|}
\hline $\begin{array}{l}\text { PRESENT SITUATION } \\
\text { MAINTENANCE }\end{array}$ & $\begin{array}{l}\text { LOCAL POPULATION ACTIVE } \\
\text { INVOLVEMENT }\end{array}$ \\
\hline $\begin{array}{l}\text { STARTING POINTS } \\
\text { - maintenance of the present protected area } \\
\text { status (natural monument) } \\
\text { - infrastructure management } \\
\text { - population stagnation and decline } \\
\text { - the present economic structure } \\
\text { maintenance }\end{array}$ & $\begin{array}{l}\text { STARTING POINTS } \\
\text { - protected areas enlargement in Slovenia } \\
\text { - sustainable development implementation } \\
\text { - maintenance and improvement of settlement and } \\
\text { demographic characteristics } \\
\text { - local (regional) economic structure } \\
\text { strengthening }\end{array}$ \\
\hline $\begin{array}{l}\text { MODES of existing Dovžan Gorge } \\
\text { management: } \\
\text { - guided tours } \\
\text { - existence of educational-research centre } \\
\text { - economic activities restrictions } \\
\text { - promotional material } \\
\text { - co-operation with the traditional } \\
\text { exhibition of minerals and fossils }\end{array}$ & $\begin{array}{l}\text { MODES of local population activation: } \\
\text { - thematic education, courses } \\
\text { - local identity strengthening } \\
\text { - protected area promotion } \\
\text { - information on implementation of sustainable } \\
\text { forms/ways in every day life }\end{array}$ \\
\hline $\begin{array}{l}\text { FIELDS of existing management: } \\
\text { - financial shortage for road infrastructure } \\
\text { maintenance } \\
\text { - insufficient maintenance of tourist } \\
\text { infrastructure } \\
\text { - absence of services } \\
\text { - educational potentials poorly used in the } \\
\text { educational-research centre }\end{array}$ & $\begin{array}{l}\text { FIELDS of local population activation: } \\
\text { - waste water, garbage management } \\
\text { - road infrastructure } \\
\text { - tourist infrastructure (signs, accompanied tourist } \\
\text { services) } \\
\text { - education and research }\end{array}$ \\
\hline $\begin{array}{l}\text { EXISTING CO-OPERATION FORMS } \\
\text { - local level co-operation missing } \\
\text { - moderate co-operation between } \\
\text { Municipality of Tržič and regional } \\
\text { professional institutions }\end{array}$ & $\begin{array}{l}\text { - CO-OPERATION FORMS for local } \\
\text { population: } \\
\text { - within the local community (Dolina-Jelendol) } \\
\text { - with the Municipality of Tržič } \\
\text { - with the regional institutions (i.e. regional } \\
\text { development agency) } \\
\text { - with professional and research institutions at } \\
\text { regional and state level }\end{array}$ \\
\hline $\begin{array}{l}\text { PROBLEM FOCUSES } \\
\text { - critical conditions of road infrastructure } \\
\text { - cultural landscape degradation } \\
\text { - lagging development } \\
\text { - unclear development vision and priorities } \\
\text { - insufficient local population activation }\end{array}$ & $\begin{array}{l}\text { PROBLEM FOCUSES } \\
\text { - unmotivated local population } \\
\text { - passivity at different levels (local, regional, } \\
\text { state) } \\
\text { - slow appropriate legislation implementation } \\
\text { - undefined financing sources }\end{array}$ \\
\hline $\begin{array}{l}\text { EXISTING CONDITIONS } \\
\text { UNRECOGNIZABLE AREA OF } \\
\text { DOVŽAN GORGE - missed economic and } \\
\text { development opportunity }\end{array}$ & $\begin{array}{l}\text { EXPECTED OUTCOME } \\
\text { RECOGNIZABLE NATURAL MONUMENT } \\
\text { OF DOVŽAN } \\
\text { GORGE - as a part of cross-border regional park } \\
\text { "Karavanke and Kamniško-Savinjske Alpe" }\end{array}$ \\
\hline
\end{tabular}


The differences between the two scenarios are especially in the field of the local population involvement, their potential activities and influences. One point was very clear: the local population is inadequately informed about the advantages that the protected areas bring. For any future positive changes, the local population needs to be motivated for their own search of new development possibilities; also the importance of natural and cultural heritage needs to be emphasized.

\section{CASE STUDY II: LAHINJA LANDSCAPE PARK}

Lahinja Landscape Park was established in 1988 through Črnomelj Municipality regulation. Within the park there are several natural as well as cultural monuments. The park protects typical cultural landscape in the south of Slovenia, as well as some typical karst phenomena as caves and karst water springs. The cultural heritage within the park represents the history of agricultural activities in the area. The main point of interest is the river Lahinja that is one of the few streams in the area that was not regulated after World War II.

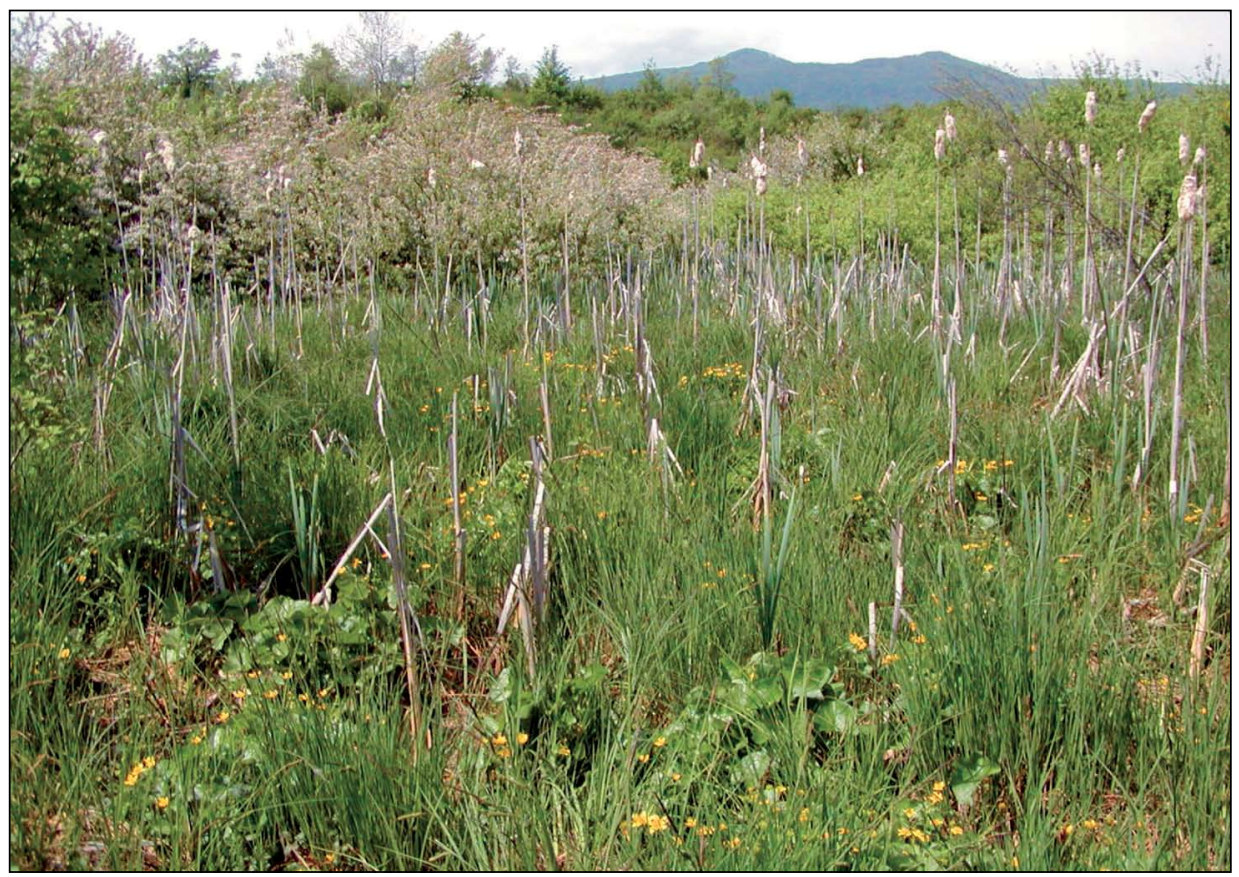

Fig. 9 The marshland called »Lahinjske luge« is protected as natural monument within the Lahinja Landscape Park.

Sl. 9. Močvara Lahinjske luge zaštićena je kao spomenik prirode u sklopu Parka prirode Lahinja.

Photo: I. Mrak 


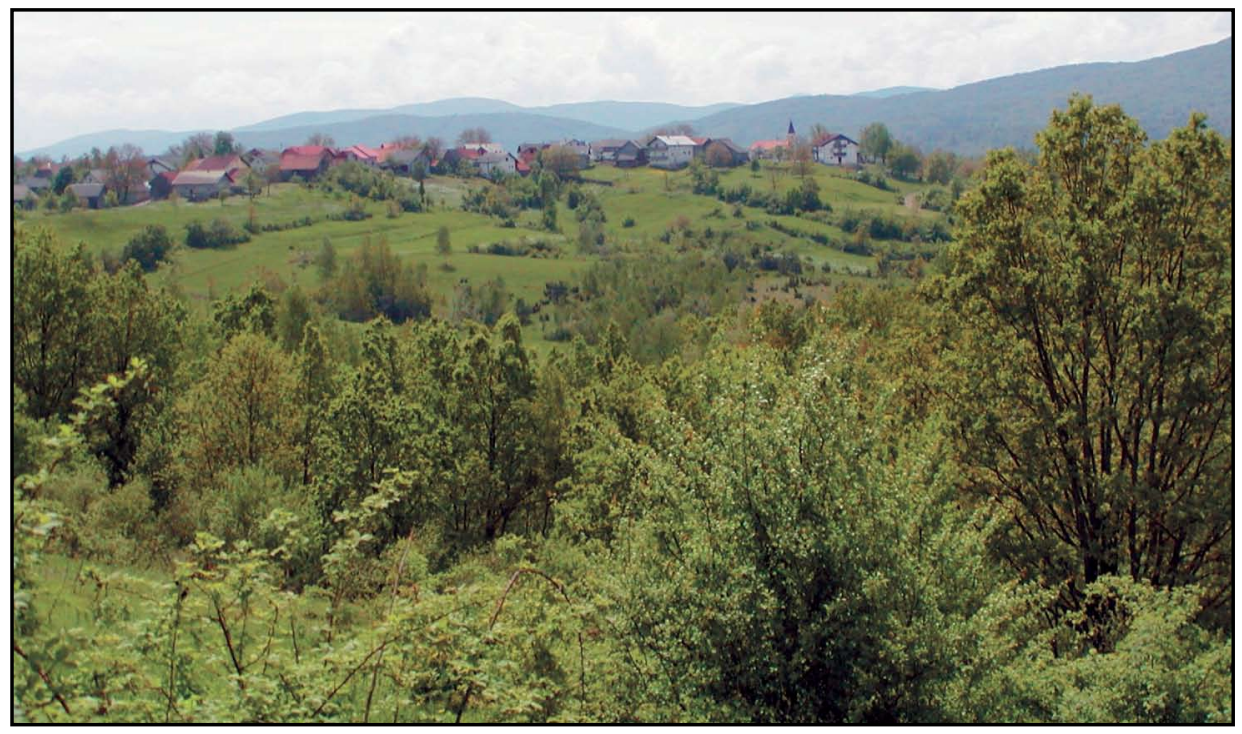

Fig. 10 The village Belčji vrh at the southern border of Lahinja Landscape Park.

Sl. 10. Selo Belčji vrh na južnom rubu Parka prirode Lahinja.

Photo: I. Mrak

There are 15 settlements within the protected area or at its border. Demographically all the settlements are declining and this fact reflects the conditions in all the region of Bela krajina. The process is the consequence of emigration that started in the second half of the $19^{\text {th }}$ century, caused by the economic recession (Plut, 1998). The population decline stopped for a while after World War II but it started again more significantly from 1961 - 2002.

Using the same methodology as in case of Dovžan Gorge Natural Monument we have interviewed (May 2004) 64 individuals in 15 settlements in and in the vicinity of Lahinja Landscape Park. The majority found the protection regime suitable, $16.4 \%$ shared the opinion that the regime is too strict, especially due to farming restrictions. Most were willing to support the potential widening of the park in the future.

As most positive effects of the protection of the natural and cultural environment, the higher numbers of visitors, better recognition of the area within Slovenia and Europe as well as overall better maintenance of settlements within the park have been emphasized. The interviewees also felt the protected area gives them better development opportunities. Among negative effects of the protected area: the bigger amount of trash, bad road infrastructure, as well as, agriculture restrictions were emphasized.

They estimated the role of Črnomelj Municipality and the role of the state mostly as "bad" (45\%), but they were personally prepared to take an active role in future park development as park managers, tour guides, shop keepers, etc. 


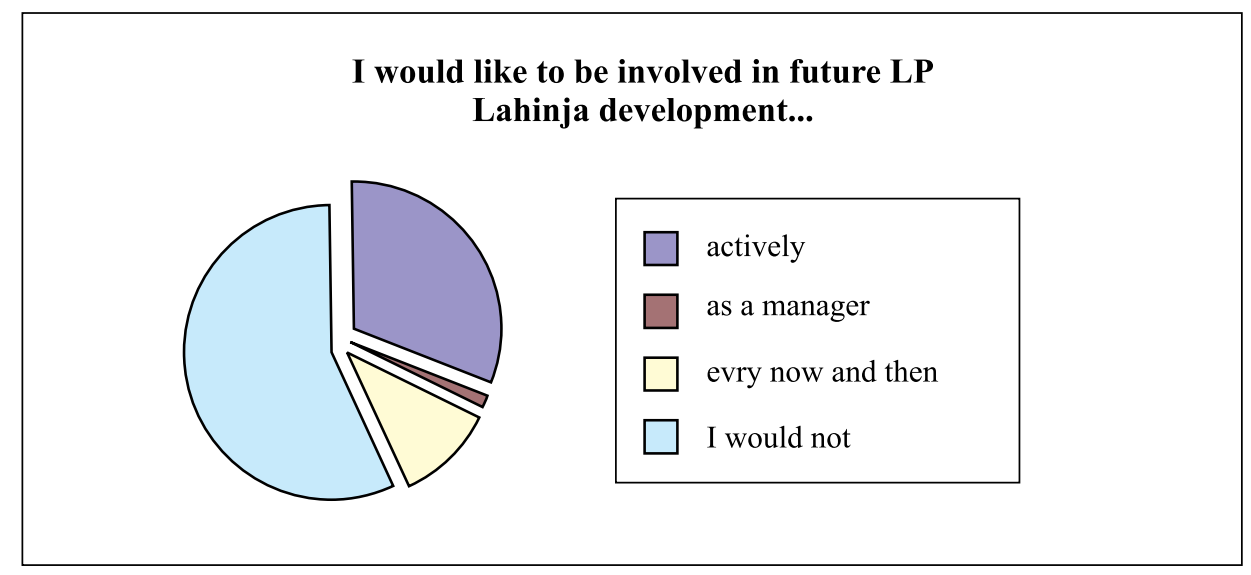

Fig. 11 Willingness to join the future park development

Sl. 11. Spremnost za uključivanje u budući razvoj parka.

Source: Field research, 2004.

Izvor: Terensko istraživanje, 2004.

The protected area LP Lahinja represents one of the main development opportunities for 15 settlements in the park area or in its vicinity. Relatively insufficient education and employment structure of the population, in researched settlements, are not positive for the future park development; but the attitude of inhabitants towards the park is very positive and they see the protected areas as the opportunity for additional income. The increased tourist visits in the area are recognized as positive but on the other hand the inhabitants are also well aware of the negative environmental impacts of intensified tourism development. The maintained cultural landscape and the curtailed process of field overgrowth shows the responsible attitude of inhabitants towards the land and the landscape that is preserved also with this protected area.

The fact that the majority of those interviewed intend to live in the area also in the future is a good sign that the long emigration process is stopping and the young generation also sees its opportunity in the future park development that will create new jobs and will consequently have also positive effect to the demographic image of the area.

\section{CONCLUSION}

Comparing to the other EU countries Slovenia has a relatively well-preserved natural environment and the high percentage of Natura 2000 areas is the coincidental consequence of past spatial planning and development. Along with rapid economic development the pressures and impacts on the natural environment are intensifying. The state inspection service is inefficient to counter the negative actions in protected areas as well as in the areas of Natura 2000. 
The new protected areas proclamation is totally dependent on political will since protected areas are widely recognized as a development obstacle. The chances for new protected areas or at least maintaining the current percentage are highly questionable. The main reason for the present situation was in the introduced approach on proclaiming the protected areas following the "top down" manner. In future the "bottom up" approach is crucial since protected areas, as well as, the areas of Natura 2000, should be recognized as one of the major Slovenian sustainable development opportunities.

The two case studies of the small sized protected areas, presented in the paper, show two different situations. Dovžan Gorge Natural Monument on one side attracted a large amount of EU and national funds; but the area is still not self sufficient, the population has not fully accepted the protected area and they are mostly not willing to participate in future development of the area, although the area is already recognized by the local authorities (Municipality of Tržič) as an important part of the local tourism offer. Dovžan Gorge Natural Monument also helps in the recognition of the wider area - Karavanke Mountains.

Lahinja Landscape Park on the other hand gives a brighter image since there were few national funds used to maintain the area but inhabitants are generally willing to participate in the future, as well as they managed to preserve the nature values and cultural landscape until today. The case is showing the importance of human resource activation as well as the value of developed social capital for encouragement of endogen regional development. The location near the Croatian border will be another development opportunity in the near future.

In both cases the present activities should remain - agriculture, forestry and tourism. Both areas are lacking a concrete management plan as well as active local population involvement in the decision making.

\section{REFERENCES}

Berginc M., 2006: Vloga države pri spodbujanju in omejevanju turističnega razvoja v zavarovanih območjih. Turizem v zavarovanih območjih. Turistična zveza Slovenije. p. 5-9.

Buser S., 1991: Vodnik po Slovenski geološki poti. Geološki zavod.

Černe A., Klemenčič M. M., Plut D., 1981: Metodologija opredeljevanja pokrajinskih enot na primeru tržiške občine. Zbornik 12. Zborovanja slovenskih geografov, Bled 1981. Ljubljana.

Dražumerič M., Hudoklin A., Ivanovič M., 1992: Krajinski park Lahinja. Založba obzorja Maribor.

Kladnik D., Ravbar M., 2003: Členitev slovenskega podeželja. Geografija Slovenije 8, Geografski inštitut Antona Melika ZRC SAZU, Ljubljana.

Klemenčič M. M., 1992: Geografski vidiki preobrazbe tržiške industrije. Geographica Slovenica 23. Ljubljana.

Knific K., 2003: Raba tal na krasu - primer iz Bele krajine. Diplomsko delo. Oddelek za geografijo FF, Univerza v Ljubljani. 
Kos J., 1978: Izseljevanje z območij nekdanjih okrajev Črnomelj in Kočevje (Po popisu iz leta 1937). Slovenski koledar 1979. Koledar za Slovence po svetu. Letnik XXVI, str. 209-216. Ljubljana. Slovenska izseljenska matica. Ljubljana, str. 1-121.

Krevs M, Lampič B., Mrak I., Ogrin M., 2006: Sustainable Environmental Research (SER) - Promoting International Cooperation and Mutual Assistance in Natural Parks; ASO -PROJECT (7-2006); final report (in printing).

Lojk J., 1960: Odseljevanje iz Bele krajine. Diplomsko delo. Oddelek za geografijo FF, Univerza v Ljubljani.

Mohorič I., 1965: Zgodovina industrije, gozdarstva in obrti v Tržiču.

Mrak I., 1993: Reliefne značilnosti ožjega območja Dovžanove soteske.

Mrak I., Potočnik Slavič I., 2005: Living in a protected area. Adjusting to restrictions or development challenge? V: PAGNINI, M.P. (ur.), JELEN, I. (ur.), SEGER, M. (ur.), BUFON, M. (ur.). Borders 3. : working papers : International scientific conference Mountains without borders, 1. edition, Tarvisio - Villach - Kranjska gora, may 3rd-5th, 2004. Trieste: Edizioni Universita. 2005. p. 83-91.

Mrak I., Zupan S., 1998: Čezmejno sodelovanje na primeru Občine Tržič. Dela 13, Oddelek za geografijo. Ljubljana, str. $301-317$.

Piskernik A., 1964: Iz zgodovine slovenskega varstva narave. Varstvo narave 2-3, 1963-1964. p. 59-74.

Plut D., 1998: Bela krajina. V: Slovenija - pokrajine in ljudje. Ljubljana, Mladinska knjiga, str. 484-495.

Premrl R. et al., 1981: Strokovne osnove prostorskega dela družbenega plana občine Tržič za obdobje do leta 1985, z elementi do leta 2000, Inštitut za regionalno ekonomiko in socialni razvoj Ljubljana. Seminarska naloga. Oddelek za geografijo, FF, Univerza v Ljubljani, str. 1-105.

Starešinič M., 2005: Sodobni regionalni problemi Bele krajine. Diplomsko delo. Oddelek za geografijo FF, Univerza v Ljubljani.

Šolar M., 2001: Pregled nastajanja Triglavskega narodnega parka. 20 let zakona o Triglavskem narodnem parku, Zbornik. Bled. 2000. p. 105-106.

Šušteršič J. et al., 2005: Strategija razvoja Slovenije. Urad RS za makroekonomske analize in razvoj, Ljubljana.

Volf D., 1994: Bela krajina kot periferna in nova obmejna regija. Diplomsko delo. Oddelek za geografijo FF, Univerza v Ljubljani.

Zupančič J., 1998: Regionalna identiteta in njena današnja vloga v lokalni samoupravi. Primera Dolenjske in Bele krajine. Rast- L.IX, št.4 (58), avgust 1998, str. 389 - 395.

Zupančič J., 2001: Meja in obmejno prebivalstvo v luči čezmejnega sodelovanja. Primer Bele krajine. Rast- L.XII, št.3-4 (75-76), julij 2001, str. 357 - 366. 


\title{
SAŽETAK
}

\section{Mala zaštićena područja - razvojni potencijali Slovenije}

\author{
Irena Mrak
}

Jedinstvena raznolikost krajolika Slovenije predočena je u pet glavnih cjelina, a to su: Alpska, Subalpska, Subpanonska, Krško-dinarska i Submediteranska. Raznolik krajolik i relativno očuvana prirodna sredina razlog su značajnog udjela zaštićenih područja i područja Natura 2000. Do 1918. zaštitom prirode na području Slovenije bavili su se samo rijetki pojedinci te turistička i lovačka društva koja su brinula o posebno vrijednim dijelovima prirode, gradili staze za posjetitelje, omogućujući prvi turistički razvoj i zaštitu prirode. 1924. glavni ured državnih šuma izdvojio je 1600 ha područja oko planine Triglav i proglasio ga "Zaštićenim alpskim parkom” na razdoblje od 20 godina. Tek 1961. Dolina triglavskih jezera proglašena je Nacionalnim parkom Triglav. Zaštićeno područje obuhvatilo je više od 2000 ha. Godine 1981. ono je povećano i sada iznosi 83807 ha.

Prema zakonu o zaštiti prirode veća zaštićena područja (nacionalni park, regionalni parkovi i parkovi prirode) pokrivaju približno $1900 \mathrm{~km} 2$ ili oko $9 \%$, a zajedno sa rezervatima i spomenicima prirode gotovo $11 \%$ slovenskog teritorija. Zbog obaveza prema EU Slovenija je uvela Naturu 2000 kao mehanizam Direktive Sabora 92/43/EEC o čuvanju prirodnih staništa, te divlje faune i flore, također i Direktive Sabora 79/409/EEC o očuvanju divljih ptica. Prosječni udio Nature 2000 u europskim državama je $15 \%$, dok je u Sloveniji puno viši, iznad 36 \%. Zahvaljujući pristupu "odozgo prema dolje", koji se uglavnom koristio prilikom određivanja novih zaštićenih područja, lokalno stanovništvo se rijetko identificira s takvim područjima i najčešće ih smatra preprekom na putu ka boljoj kvaliteti života.

Od 2003. do danas istraživanje “Život u zaštićenom području u Sloveniji” odvija se na Odsjeku za geografiju (Filozofski fakultet) Sveučilišta u Ljubljani. Istraživanje se već provodi u zaštićenim područjima različitih kategorija zaštite u različitim regijama Slovenije.

U ovom radu prikazana su dva istraživana područja: spomenik prirode Dovžanov kanjon smješten u Karavankama blizu austrijske granice i Park prirode Lahinja lociran u jugoistočnom dijelu Slovenije na granici s Hrvatskom. Dovžanov kanjon je, s jedne strane, uživao veliku financijsku potporu (domaću i EU), međutim, područje još nije samodostatno jer lokalno stanovništvo nije prihvatilo zaštićeno područje i uglavnom nije spremno sudjelovati u budućem razvoju istog. S druge strane, Park prirode Lahinja pruža svjetliju sliku iako je malo nacionalnog novca utrošeno za održavanje područja, no lokalno je stanovništvo većinom spremno sudjelovati u njegovom razvoju.

Zajedno s brzim ekonomskim razvojem, uvelike se pojačavaju pritisci i utjecaji na prirodnu sredinu. Služba državne inspekcije nije efikasna u neutralizaciji tekućih negativnih postupaka u zaštićenim područjima, kao ni u područjima Natura 2000.

Proglašenje novih zaštićenih područja u potpunosti ovisi o političkoj volji. Kako se smatra da zaštićena područja uvelike opterećuju razvitak, prigoda za nova zaštićena područja ili barem održavanje postojećeg postotka je pod velikim upitnikom. U budućnosti, pristup "odozdo prema gore" 
je od presudne važnosti, jer bi zaštićena područja, kao i područja Natura 2000, trebala predstavljati jednu od glavnih prilika za održivi razvoj u Sloveniji.

Received (Primljeno): 2007 - $01-23$

Accepted (Prihvaćeno): 2007 - 12 - 04

Irena Mrak, MSc.,

University of Ljubljana, Department of Geography,

Aškerčeva 2, 1000 Ljubljana, Slovenia e-mail: irena.mrak@siol.net 
